\title{
The Investigation of Moral Judgement Competence of High School Students in Terms of Parental Attitudes"
}

\author{
Sedef ÜNSAL SEYDOOĞULLARI** Nermin ÇİFTÇİ ARIDAĞ ${ }^{* * * *}$ \\ Mustafa KOÇ****
}

\begin{abstract}
The purpose of this study is to examine the moral judgment competence of students attending to high school in terms of parental attitudes. The participants of the study consist of 447 students. The data was collected by using Moral Judgment Test of Lind, Parental Attitude Scale and Personal Information Form. The Data was analysed with $t$ test, one way ANOVA and Tukey as a posthoc test. In the study, moral judgment scores of students did not differ significantly according to the parental attitude. Moral judgment scores of students attending to science and anatolian high school were significantly higher than attending to the vocational high school. The students whose parents had a university education, scored higher than parents had an elementary education. Moral judgment scores of students did not differ significantly according to their perceived economic level.
\end{abstract}

Keywords: Moral judgement competence, parental attitude, type of high school, students of high school, adolescents

\footnotetext{
The subject matter of this article is the same with the thesis prepared by Sedef Ünsal Seydooğulları titled "The Effects of the Attitudes of Democratic and Authoritarian Parents on Moral Judgement Ability of the High School Students" under the supervision of Assistant Professor Dr. Mustafa Koç. Apart from the original sections of the thesis such as the introduction, literature review, analysis, discussion and works cited, the new data and the literare have been added and rewritten by Sedef UNSAL SEYDOOGULLARI and Assistant Professor Dr. Nermin CIFTCI ARIDAG.

Ankara University Student of Doctorate, Cahit ElginkanAnatolian High School. Kocaeli, Turkey. email: sedefunsal@gmail.com

*** Assistant Professor Dr.,Yıldiz Technical University, Faculty of Education Department of Education Sciences. Istanbul, Turkey. e-mail: neciftci@yildiz.edu.tr

${ }^{* * * *}$ Associate Professor Dr., Sakarya University, Faculty of Education Department of Education Sciences. Sakarya, Turkey. e- mail: mkoc@sakarya.edu.tr
} 


\section{SUMMARY}

Purpose and Significance: Effect of family attitude on the moral development of children and adolescent hasn't been investigated sufficiently in our country. However, family is the most important source of effect in moral development. It is also the first important environment in moral socialization. (White \& Matawie, 2004). Consistency, nearness, communication and dependable family environment have been determined as variants which interprete the content of adolescent thinking. In addition to nearness; importance of dependence, patience and consistency are emphasized by Kohlberg (1964). Consequently the aim of this research is to investigate moral judgment competence of high school students in terms of parental attitude. Sub- intents of the research are type of high school, education level of parents and perceived economic level.

Method: The participants of the study consist of 447 students who attend to anatolian high school, vocational high school, general high school and science high school. The data was collected with Moral Judgement Abilities Test (MJT) developed by Lind (1977) and adapted into Turkish by Çiftçi (2001a, 2001b), Parents Attitude Scale (PAS) developed by Bilal (1984) and Personal Information Form developed by author to determine demographic features. The data analyses were checked with $t$ test, one way ANOVA and tukey as a post-hoc test.

Results: According to the finding of research; moral judgment scores of students did not differ significantly in terms of parental attitude. When moral judgement competence was examined according to type of high school; moral judgement scores of students attending to science high school and anatolian high school are higher than moral judgment scores of students attending to the vocational high school. Moreover, moral judgement scores of students differ significantly according to their parents' level of education. Families are critically important in terms of social, psychological and moral development of a person's life. The result of this case can be that families who have high level of education can give more chance. Moral judgment scores of students did not differ significantly according to perceived economic level.

Discussion and Conclusion: Moral judgement scores of students did not differ significantly according to parental attitude. This result is different from literature. One of the reason of this result can be related to the structure 
of the test. The test measures perceived mother and father attitude. But real attitude can be different from perceived attitude. Accordingly it is difficult to measure the real attitude. Moral judgement scores of students attending to science high school and anatolian high school are higher than moral judgement scores of students attending to the vocational high school. This result may depend on education, family and variety of curriculum programs followed by the students. In this research moral judgment scores differ significantly according mother's and father's level of education. Parents have an important role in a person's life in terms of social, psychological and moral development. The result of this case is possibly that parents with high level of education can provide the environment which supports the moral development or the sensibility of justice with for their children. 



\title{
Lise Öğrencilerinde Ahlaki Yargı Yeteneğinin Anne- Baba Tutumları Açısından İncelenmesi"
}

\author{
Sedef ÜNSAL SEYDOOĞULLARI** Nermin ÇIFTÇİ ARIDAĞ ${ }^{* * *}$ \\ Mustafa KOÇ****
}

ÖZ: $\mathrm{Bu}$ araştırmada lise öğrencilerinin ahlaki yargı yetenekleri ana baba tutumlarına göre incelenmiştir. 447 öğrencinin katıldığ araştırmada öğrencilerin ahlaki yargı yeteneklerinin lise türüne, anne ve babalarının eğitim düzeyine, algılanan sosyo-ekonomik düzeye göre incelenmiștir. Veriler; Ahlaki Yargı Testi, Anne Baba Tutum Ölçeği, Kişisel Bilgiler Anketi ile toplanmıştır. Verilerin analizinde, $t$ testi, tek yönlü varyans analizi kullanılmıştır. Anne-baba tutumlarına göre öğrencilerin ahlaki yargı yetenekleri arasında anlamlı bir fark saptanamamıştır. Araştırma sonucuna göre fen lisesi ve anadolu lisesindeki öğrencilerin ahlaki yargı yeteneği puanları meslek lisesindeki öğrencilerin ahlaki yargı yeteneği puanlarından anlamlı düzeyde yüksek bulunmuştur. Annesi ve babası üniversite mezunu olan öğrencilerin ahlaki yargı yeteneği puanları, annesi ve babası ilkokul mezunu olan öğrencilerin ahlaki yargı puanlarından anlamlı düzeyde yüksek bulunmuştur. Öğrencilerin algıladıkları sosyoekonomik düzeylerine göre ahlaki yargı puanlarında anlamlı bir farklılık saptanamamıştır.

Anahtar Sözcükler: Ahlaki yargı yeteneği, anne baba tutumu, lise türleri, lise öğrencileri, ergenler

\footnotetext{
* Bu makalenin konusu birinci yazar tarafından, üçüncü yazarın danışmanlığında yürütülmüş olan "Demokratik ve Otoriter Ana Baba Tutumlarının Lisede Öğrenim Gören Öğrencilerin Ahlaki Yarg1 Yeteneğine Etkisi” adlı tezin konusu ile aynıdır. Ancak tezin makaleyi dönüştürülmesi sürecinde, tezden farklı olarak makalenin giriș, ilgili literatür, analiz, tartıșma, kaynaklar bölümleri birinci ve ikinci yazar tarafından yeni veriler ve de literatür eklenerek yeniden yazılmıştır.

Ankara Üniversitesi Doktora Öğrencisi, Cahit Elginkan Anadolu Lisesi, Kocaeli, Türkiye. E- mail: sedefunsal@gmail.com

${ }^{* * *}$ Yrd. Doç. Dr., Yıldız Teknik Üniversitesi Eğitim Fakültesi Eğitim Bilimleri Bölümü Psikolojik Danıșma ve Rehberlik ABD. İstanbul, Türkiye. E-mail: neciftci@yildiz.edu.tr

**** Doç. Dr., Sakarya Üniversitesi Eğitim Fakültesi Eğitim Bilimleri Bölümü Eğitimde Psikolojik Hizmetler ABD. Sakarya, Türkiye. E- mail: mkoc@sakarya.edu.tr
} 


\section{GİRIŞ}

$\mathrm{Bu}$ araştırmanın amaca lise öğrencilerinin ahlaki yargı yeteneklerini anne baba tutumları açısından incelemektir. Birçok filozof ve sosyolog, ahlaki düzenin oluşturulmasını toplumların çekirdeği olarak görmektedir (Durkheim, 1973; Mead 1962/1934; Rousseau, 2004/1762). Evrensel değer ve doğruların olduğu görüşünden hareket eden Kohlberg'e göre ahlak; hakhaksızlık, doğru-yanlış konularında bilinçli bir yargılama ve karar vermeyi, alınan karar doğrultusunda davranmayı da kapsayan, bilişsel bir yapıdır. Diğer bir deyişle ahlak, bireyin kendisinin belirlediği - evrensel ilkelerle de örtüşebilecek nitelikteki - ilkelere göre yargıda bulunması, kararlar alması ve onlara uygun davranabilmesi yeteneğidir (Kohlberg, Levine \& Hewer, 1996/1984).

İnsanların ahlaki ikilemlerle karşılaştıklarında ahlaki yargılamalarını nasıl yaptıklarına odaklanan Kohlberg'in modelinde, ahlaki gelişimin yapısı hiyerarşik ve değişmez basamaklar düzeninde betimlenmiştir. Ahlaki gelişim sürecinde, insanların bencil ve çıkarcı bir bakış açısından karşılıklı dayanışma ve başkalarına karşı olgun bir ilgi gösterme noktasına doğru geliştikleri ileri sürülmüştür. Adalet değerine odaklı olarak tanımlanan ahlak; çocukluktan yetişkinliğe doğru her biri kendi içinde iki basamağ içeren, üç düzeyde gelişen altı basamaklı yapısal bir modelde açıklanmıştır (Kohlberg, 1974). Ahlaki yargının gelenek öncesi, geleneksel ve gelenek sonrası olarak gruplandırılan düzeylerinde, sırasıyla altı basamak bulunmaktadır. Her bir basamak insanların ahlaki ikilemleri, giderek daha nitelikli bir muhakeme yeteneği biçiminde yargıda bulunmaları için bilişsel bir olanak vermektedir (basamakların içeriğinin detaylı açıklaması için bk. Çiftçi, 2003a, 2003b, 2009; Gielen, 1996; Kuhmerker, Gielen \& Hayes, 1996; Lind, 2008a). Kohlberg'e göre, bu basamaklar değişmez bir süreci hedefler ve izler. Önceki basamağın yerine geçen yeni bir basamak ahlaki problemlerin daha gelişmiş bir yapıdaki bilişsel çözümünü sağlar. Gelişim sürecinde hiç bir basamak atlanmaz ve öncekine geri dönülemez. Ahlaki gelişimin bittiği düzey bireylere göre farkl1lık gösterir. Fakat en üst düzeye çok az insan ulaşır. Kohlberg, ahlak gelişimi için iki faktörü sorumlu görmektedir: Bilişsel yeteneklerin artması - ki bu ahlaki muhakemenin gelişimini sağlayan - ahlaki yargının ve ardından gelen davranışın temelidir ve sosyal etkileşimle kazanılan perspektif alma sürecidir (Kohlberg \& Candee, 1996/1984). Kohlberg ile birlikte çalışmış olan Lind, Almanya'da Kohlberg'in en önemli takipçileri arasında sayılmaktadır. Ahlaki gelişimde Dual Aspekt Modelini geliştirmiş olan Lind'e göre (1986) ahlak demokratik kişiliğin çekirdeğidir; Lind'e göre demokrasi bir kral, bir diktatör, bir sinıf yerine, bireyin haklarını, özgürlüğünü, eşitliğini ve adaleti koruyan, evrensel ahlak 
ilkelerinde somutlaşmış olan ilkelerin iktidarda olması demektir. Lind'e göre, ahlaki yarg1 yeteneği, Konstanz İkilem Tartışmaları Yöntemi (KMDD) ile geliştirilebilmektedir.

Ergenlik dönemindeki en önemli gelişim alanlarından biri bilişsel gelişime paralel olarak ilerleyen ahlaki gelişimdir. Son çocukluğun ardından erken ergenlik döneminde, somut işlemler döneminden soyut işlemler dönemine geçiş başlar (Piaget, 1965). Böylece ergenler, çocukluktaki benmerkezci bakış açısıyla bireysel çıkarların ön planda olduğu ahlaki bakış açısından, toplumun geleceğinin ve bireyin sorumluluklarının dikkate alınmaya başlandığı sözleşmeler ahlakının yaşandığı bir döneme doğru ilerler (Colby \& Kohlberg, 1986). Sağliklı bir gelişim sürecinden geçen ergen, toplumun ve insanlığın geleceği ve sorunlarıyla ilgilenir, çözüm yollarını düşünür, bu çözümde kendisi de sorumluluk almak ister. Bütün bunlardan dolayı, bu dönemdeki ahlaki gelişimin önemi artmaktadır.

Farklı araştırmacılar tarafından aynı anlama gelen farklı kavramlar kullanılsa da, çocuk yetiştirme stilleri iki temel boyuta dayanılarak sinıflandırılmaktadır: “Anne Baba Kontrolü" ve "Anne Baba Kabulü”. Anne baba kontrolü anababanın çocuğu toplumsallaştırma isteğine ve buna dayanarak çocuğu topluma hazırlamaya işaret etmektedir. Anne-baba kabulü ise anababanın çocuğun bireyselliğini tanıması ve kabul etmesini tanımlamaktadır (Darling ve Steinberg, 1993).

Birçok araştırmacının (Dunton, 1988; Smetana, 1999) aile ile ilgili çalışmalarında atıfta bulunduğu Baumrind (1991) ebeveynlik tarzlarını; "kontrol düzeyi- talepkarlık" ve ebeveyn sıcaklığının düzeyi, çocuğa karş1 gösterilen "duyarlılık" olmak üzere iki boyutta kategorize etmiştir. Baumrind'e göre anababalar çocuklarını kontrol ederek; onlara danışmanlık yaparak, yaptırım uygulayarak, denetleyerek ve de çocuktan olgunluk talep ederek onların aileye uyumunu sağlamaya çalışırlar. Böylece kurallara uymayanların kurallara uyması amaçlanır. Baumrind'e göre (1991) ebeveynlerin bu türden çabaları kontrol ve talepkarlık tutumları ile ilişkili iken; anababa kabulü ise bireyselliği ve öz düzenlemeyi desteklemek, çocuğun özel gereksinimlerinin farkında olmak ve onları desteklemek olarak tanımlanır. Ona göre anababa kabulü bakım, kabul, destek ve bağlanma kavramları ile benzerlik göstermektedir.

Maccoby ve Martin (1983) ileri sürdükleri duyarlılık ve talepkarlık boyutlarına dayanarak; "demokratik", "otoriter", "izin verici şımartan" (permissive indulgent) ve "izin verici ihmalkar" (permissive neglegting) olmak üzere dört çocuk yetiştirme stili ortaya koymuşlardır. Onlara göre demokratik anababalar "talep ve duyarlılık" boyutlarını çocuğun gereksinimlerine göre ayarlayabilmektedirler. $\mathrm{Bu}$ stilde hem anababa kontrolü hem de kabulü vardır. Bu anne-babalar belli bir disiplin uygularken 
aynı zamanda çocuğun mantıklı isteklerine karşı da duyarlı olurlar. $\mathrm{Bu}$ tutum, çocuk ve ergenlerde olumlu gelişimsel sonuçlara, benlik saygisının gelişmesine, okul başarısına zemin hazırlar (Grolnick ve Ryan, 1989). Otoriter anababaların ise talepkarlık düzeyleri yüksek, duyarlılık düzeyleri düşüktür. $\mathrm{Bu}$ anababaların kontrol düzeyleri yüksek kabul düzeyleri düşüktürler. Çocukların isteklerine katı kurallar koyarlar ve bu kuralları çocukla tartışmazlar. Bu tür anne-babalar çocukları üzerinde güç uygularlar. Genellikle bu anne-babalar, çocuklarının ihtiyaçlarına duyarlı değil cezalandırıcı olurlar ve şefkatli davranmazlar. Otoriter tutum, çocuklarda ve ergenlerde duygusal ve sosyal uyumsuzluklara, ahlaki zayıflık, düşük özsayg1 ve saldırgan davranışlara neden olur (Steinberg v.d. 1994).

Yurtdış1 alanyazında ahlaki yarg1 gelişiminde ailenin rolüne yönelik araştırmaların daha fazla olduğu gözlenmiştir: Holstein'ın (1972) araştırmasında, aile sıcaklığı ve bağlılığ ile çocukların ahlaki yarg1 düzeyinin yüksekliği arasında ilişki bulunmuştur. Powers (1988) ve Speicher $(1992,1994)$ sıcaklık, duygulanım, tutum ve etkileşim, tartışma şekilleri ve disiplin yöntemleri gibi aile koşullarının ve ebeveynlerin çocukların ahlaki yargı basamaklarının gelişimindeki önemini ortaya koymuşlardır. White ve arkadaşlarına göre aile, ergenlerin ahlaki gelişiminde en önemli etki kaynağıdır ve ahlaki sosyalleşmede ilk önemli ortamdır (White \& Matawie, 2004). Ergenlerin ahlaki gelişimi ile ailenin destekleyici tutumu arasında pozitif ilişki olduğu sonucunu destekleyen çalışmaların yanında (Grusec, 2000; Taris, 2000), çocukların ahlaki yarg1 gelişiminde ailenin en önemli etki kaynağı olduğunu vurgulayan çok sayıda araştırma yapılmıştır ( Beck, 1989; Lamb, 1993; Schickedanz, 1994, Berkowitz \& Grych, 1998; Hart ve diğerleri, 1999; Okin \& Reich, 1999; Pratt ve diğerleri, 1999; Rudy ve diğerleri, 1999; Smetana, 1999; Spinrad ve diğerleri, 1999; Walker, 1999; Walker \& Hennig, 1999; Royal \& Baker, 2005). Speicher (1992) ve Gibbs (1991) araştırmalarına dayanarak, sosyal ve ailesel süreçlerin ahlaki yargı gelişiminde önemli bir rol oynadığını ileri sürmüşlerdir.

Türkiye'de ahlaki yarg1 yeteneği ile anne-baba tutumları arasındaki ilişkiyi inceleyen çalışma sayısı oldukça azdır. Yapılan araştırmaların bulguları incelendiğinde yabancı literatürü destekleyen çalışmalara rastlanmıştır. Örneğin Özeri (2001) tarafindan okul öncesi dönem çocuğunun suça yönelik adalet gelişimi ile göreve yönelik adalet gelişimine anne-baba tutumlarının etkisi incelenmiş; annenin koruyucu tutumunun, ahlaki yargıyı olumsuz etkilediği sonucuna varılmıştır. Tola'nın (2003), beşinci sınıf öğrencileriyle yaptığı araştırmada, Piaget'in geliştirdiği öykü ve problem durumları kullanılarak ahlaki yarg1 yeteneği ölçülmüş ve öğrencilerin öykülere verdiği cevaplara göre; demokratik tutumun ailesinde şiddet olan öğrencilerle ailesinde şiddet olmayan öğrencilerin ahlaki yarg1 yetenekleri 
arasında da anlamlı bir farklılık bulunamamıştır. Aynı araştırmada cinsiyete ve anne babanın eğitim durumuna göre de bir karşıllaştırma yapılmış ve kız ve erkeklerin ahlaki yargı yetenekleri puanları arasında anlamlı bir farklılık bulunamamıştır; annenin ve babanın eğitim düzeyleri ile ahlaki yargı yeteneği arasında da anlamlı bir farklılık saptanamamıştır.

Yurtdışı literatürde, lise türlerine göre ahlaki yarg1 yeteneğinin incelendiği araştırmaya rastlanamamış, Türkiye'deki literatürün de sınırlı olduğu görülmüştür. Kaya'nın (1993) üniversite öğrencileri ile yaptığı araştırmasında, imam hatip lisesinden mezun olan üniversite öğrencileriyle diğer liselerden mezun olan öğrencilerin ahlaki yarg1 yeteneği puanları arasında anlamlı bir farklılık saptanamamıştır.

Türkçe literatürde, genelde, imam hatip lisesinde öğrenim gören ve görmeyen öğrencilerin ahlaki muhakeme düzeylerini karşılaştıran araştırmalar vardır (Kaya, 1993; Şengün, 2008). Ancak diğer lise türleri arasında karşılaştırma yapan çalışmalar sınırlı sayıdadır (Çileli, 1981; Çiftçi, 2001a; Çırak, 2006). Bu araştırmaların sonuçları ise lise türlerine göre öğrencilerin ahlaki yarg1 yetenekleri arasında anlamlı bir farkl111k bulunmadığ 1 yönünde olup, öngörüleri desteklememektedir. Örneğin; Çileli tarafindan (1981) Londra'da iki farklı lisedeki öğrenci grubu üzerinde DIT’i kullanarak yapılan araştırmanın sonuçları da, lise türleri bakımından ahlaki yarg1 yeteneğinin herhangi bir farklılık göstermediği yönündedir. Çiftçi'nin (2001a) araştırmasında da lise türlerine göre öğrencilerin ahlaki yargı yeteneği puanları arasında anlamlı bir fark bulunamamıştır. Çırak'ın (2006) DIT'i kullanarak, üniversite öğrencilerinin ahlaki yarg1 yetenekleri ile kendini gerçekleştirme düzeylerini karşılaştırdığı araştırmasında da, ahlaki yarg1 yeteneğinin lise türlerine göre anlamlı bir farklılık göstermediği bulunmuştur. Ahlaki yarg1 yeteneği ile anne ve babanın eğitim düzeyinin karş1laştırıldığ , Fodor'un (1969) çalışmasında anneleri lise mezunu olan çocukların ahlaki yargılarının diğerlerine göre anlamlı düzeyde farklı olduğu tespit edilmiştir.

Koca'nın (1987) araştırmasında da annenin eğitim durumu değişkeni açısından haklı- haksız kavramlarıyla ilişkili olarak yapılan yargılar arasında anlamlı bir fark bulunmuştur. Özeri (1994) tarafindan yapılan araştırmada annenin eğitim düzeyinin ahlaki yargıyı etkilediği sonucuna ulaşılmıştır. Yine Çırak'ın (2006) üniversite öğrencileriyle yaptı̆̆ 1 araştırmada annesi okuryazar veya ilkokul mezunu olan öğrencilerin, okuryazar olmayanlar ile ortaokul, lise ve üniversite mezunu olanlara göre, daha geleneksel olduğu bulunmuştur. Bu konudaki Mangır ve Haktanır (1990), İkizoğlu (1993) ve Çırak (2006) tarafindan yapılan araştırmalarda ahlaki yarg1 yeteneği ile annenin eğitim düzeyi arasında pozitif bir ilişki olduğu yönünde sonuçlara ulaşılmıştır. Ulaşılan bazı araştırmalarda ise; sonuçlar annenin eğitim 
düzeyinin ahlaki yargıyı etkilemediği yönündedir (Özkaynak, 1982; Koca, 1987; Kaya, 1993; Şengün, 2003; Tola, 2003; Acuner, 2004; Küçükalp, 2004; Çapan, 2005; Çiftçi, 2008).

Literatürdeki araştırma sonuçlarına göre ahlaki yargı yeteneği ile sosyoekonomik durum arasında anlamlı bir ilişki bulunamamıştır. Sosyo ekonomik statü ve ile ahlaki yargı arasındaki ilişkinin incelendiği araştırmada Kohlberg'in Ahlaki Yargı Envanteri uygulanmış, sosyoekonomik statü ile ahlaki yargı arasında anlamlı bir ilişki görülmemiştir. Ulaşılan diğer araştırmalarda (Lind, 1983; Hayes ve Hambright, 1984) ahlaki yarg1 yeteneği ile sosyo-ekonomik düzey arasında ilişki olmadığ 1 saptanmıştır (Kaya, 1993; Şengün, 2003; Küçükalp, 2004; Çiftçi, 2008). Ancak literatürde farklı araştırma sonuçları da bulunmaktadır: Turiel, Edward ve Kohlberg (1978) tarafından Türkiye'de Manisa'nın bir köyünden 52 kişi, İzmir'de işçi sınıfından 29 kişi ve Ankara' da orta sosyo- ekonomik düzeyden 32 kişi olmak üzere yaşları 10 ile 25 yaş arasında değişen toplam 113 kişi üzerinde Kohlberg'in Ahlaki İkilem Anketinin (MMS) Türkçe formu uygulanarak yapılan araştırmada; sosyo- ekonomik düzeyi farklı olan kişilerin ahlaki yargılarının şehirde yaşayanlar lehine farklı bir gelişim gösterdiği gözlenmiştir. Türkiye'deki literatüde de Saylağ'ın ( 2001) çalışmasında benzer bulguya rastlanmıştır; lise birinci sınıf öğrencileri üzerinde yapılan bu araştırmada ailenin sosyo-ekonomik durumunun öğencilerin ahlaki değerlerinde etkili olduğu sonucuna varılmıştır.

İlgili yurtdışı alanyazın ile karşılaştırıldığında, ülkemizde ahlaki yargı yeteneği gelişiminin anne baba tutumları açısından yeterince incelenmediğ görülmektedir. $\mathrm{Bu}$ nedenle bu çalışmanın amacı da lisede eğitim gören öğrencilerin ahlaki yargı yeteneği düzeylerini "otoriter" ve "demokratik" olarak algılanan anne-baba tutumu açısından incelemektir. Bu kapsamda, bu araştırmada öncelikle yanıt aranan sorular, şunlardır:

1. Öğrencilerin okudukları lise türüne göre ahlaki yargı yeteneği puan ortalamaları arasında anlamlı bir fark var midir?

2. Anne ve babalarının eğitim düzeylerine göre, öğrencilerin ahlaki yarg1 yeteneği puan ortalamaları arasında anlamlı bir fark var mıdır?

3. Algılanan sosyo-ekonomik düzeye göre öğrencilerin ahlaki yargı yeteneği puan ortalamaları arasında anlamlı bir fark var mıdır?

4. Anne-baba tutumlarını "demokratik ve otoriter" olarak algılayan lise öğrencilerinin ahlaki yarg1 yeteneği puan ortalamaları arasında anlamlı bir fark var midır? 


\section{YÖNTEM}

\section{Araştırmanın Modeli}

$\mathrm{Bu}$ araştırmanın modeli, Büyüköztürk vd. (2011) de ifade ettiği gibi "insan grupları arasında farklılıkların nedenlerini ve sonuçlarını koşullar ve katılımcılar üzerinde herhangi bir müdahale olmaksızın belirlemeyi amaçlayan" nedensel karşılaştırma araştırmasıdır.

\section{Evren ve Örneklem}

Araştırmanın evreni, İstanbul'un Kartal ve Kadıköy ilçeleri ve Kocaeli'ndeki resmi liselere devam eden öğrenciler oluşturmaktadır. Uygulama yapılan liselerden üçü random örnekleme yoluyla biri ise uygun örnekleme yoluyla seçilmiştir. Araştırmanın örneklemini 447 öğrenci oluşturmuştur.

Araştırmaya Kadıköy Prof. Faik Somer Anadolu Lisesi ve İzmit Cahit Elginkan Anadolu Lisesi'nden 181 (\% 40); Yakacık Hacı İsmail Gündoğdu Ticaret Meslek Lisesi'nden 92 (\% 21); Kadıköy Prof. Faik Somer Lisesi'nden 88 (\% 20), İstanbul Atatürk Fen Lisesi'nden 86 (\% 19) olmak üzere toplam 447 öğrenci katılmıştır. Katılımcıların 214'ü kız (\% 53), 191’i erkek (\% 47) öğrencidir. Analizler bazı değişkenlerdeki boş veriler nedeniyle 419 öğrencinin verisi üzerinde yapılmıştır.

\section{Veri Toplama Araçları}

Araştırmada, ahlaki yargı yeteneğini ölçmek için Lind (1978) tarafından geliştirilen, Türkçesi ile birlikte 39 dile tercüme edilmiş ve geçerlik çalışmaları yapılmış olan Ahlaki Yargı Testi (AYT) kullanılmıştır. (Çiftçi, 2001a, 2001b). Anne-baba tutumlarını ölçmek için Bilal (1984) tarafindan geliştirilen Anne Baba Tutum Ölçeği (ABTÖ), demografik özellikleri belirlemek için ise yazar tarafindan geliştirilen Kişisel Bilgiler Anketi kullanılmıştır; öğrencilerin algıladıkları sosyo-ekonomik durumlarını "düşük", "orta", "yeterli", "iyi” ve "yüksek" şıklarından seçmeleri istenmiştir.

Ölçek uygulaması gönüllülük esasına göre, 50 dakikalık sürede, doldurulmuştur. Cevaplama süresince ve anketler toplanırken gizlilik ilkesine özen gösterilmiştir. Verileri analiz etmek için tek yönlü varyans analizi ve t-testi kullanılmıştır. Veriler SPSS-15 paket programı ile analiz edilmiştir.

\footnotetext{
Kadıköy Prof. Faik Somer Anadolu Lisesi, İstanbul Atatürk Fen Lisesi ve Yakacık Hacı İsmail Gündoğdu Ticaret Meslek Lisesi araştırmacının tezinde kullandığı örneklemdir. Cahit Elginkan Anadolu Lisesi ise mevcut çalışma kapsamında makale hazırlama sürecinde uygun örnekleme yoluyla seçilmiştir.
} 


\section{BULGULAR}

Araştırmada ahlaki yarg1 yeteneğini ölçmek için kullanılan Lind'in rasyonel, deneysel test teorisine göre geliştirmiş olduğu Ahlaki Yarg1 Testi'nden 0-100 arasında puan alınabilmektedir. Araştırma grubunun ahlaki yargı puanları 0-62 puan arasında değişmektedir, puanların \% 87'si (ahlaki bir odaklanmanın başlangıcının göstergesi olan) 30 puanın altındadır ve ortalaması da 15.38 'dir.

1. Öğrencilerin ahlaki yarg1 yeteneği puan ortalamalarının eğitim gördükleri lise türlerine göre faklılaşıp faklılaşmadığı tek yönlü varyans analizi ile incelenmiş, ahlaki yargı yeteneği puanlarının lise türlerine göre anlamlı farkl1lık gösterdiği bulunmuştur $\left[\mathrm{F}_{(3-385)}=5,242 ; \mathrm{p}<, 05\right.$. ]. Buna göre posthoc testlerden Tukey analiz sonuçlarına göre; fen lisesi ( $\bar{X}=16.60)$ ve anadolu lisesinde $(\bar{X}=17.13)$ eğitim gören öğrencilerin ahlaki yargı yeteneği puanları ortalamaları meslek lisesinde eğitim görenlerin ahlaki yargı yeteneği puan ortalamasından $(\bar{X}=11.02)$ anlamlı düzeyde yüksek bulunmuştur $(\mathrm{p}<.05)$.

2. Annenin eğitim düzeyine göre öğrencilerin ahlaki yarg1 yeteneği puan ortalamalarının farklılaşıp farklaşmadığı tek yönlü varyans analizi ile incelenmiş, gruplar arasında fark olduğu belirlenmiştir $\left[\mathrm{F}_{(3-380)}=4.212 ; \mathrm{p}<\right.$ 0.05]. Posthoc testinde (Tukey ) annesi ilkokul mezunu olan öğrencilerin ahlaki yargı yeteneği puan ortalaması ( $\bar{X}=13.17)$ anlamlı düzeyde düşük bulunmuştur. Babanın eğitim düzeyine göre öğrencilerin ahlaki yargı yeteneği puan ortalamaları tek yönlü varyans analizi ile incelendiğinde gruplar arasında fark olduğu belirlenmiştir $\left[\mathrm{F}_{(3-379)}=3.003 ; \mathrm{p}<0.05\right]$. Yapılan posthoc testinde (Tukey) babası üniversite mezunu olan öğrencilerin ahlaki yargı yeteneği puan ortalamalarının (17.53), babası ilkokul mezunu olan öğrencilerin ahlaki yarg1 yeteneği ortalamasından $(\bar{X}=13.14)$ anlamlı düzeyde yüksek olduğu tesbit edilmiştir.

3. Öğrencilerin algıladıkları sosyo-ekonomik düzeylerine göre ahlaki yarg1 yeteneği puanları incelendiğinde sosyo-ekonomik düzeye göre gruplar arasında fark bulunamamıştır $\left[\mathrm{F}_{(6-371)}=0.701 ; \mathrm{p}>0.05\right]^{*}$.

4. Araştırmanın bulgularına göre annesini demokratik olarak algılayan öğrencilerin sayısı 252'dir (\% 60), otoriter olarak algılayan öğrenci sayısı ise 167 'dir (\% 40). Anne tutumunu demokratik olarak algilayan öğrencilerin ahlaki yargı yeteneği puanı ortalaması $(\bar{X}=15.91)$ ile otoriter olarak

\footnotetext{
Araştırmamızın alt amaçları arasında yer almamakla beraber, bu konuda çalışmak isteyen araştırmacıları bilgi vermek gerekirse, cinsiyete göre ahlaki yargı puan ortalamaları karşılaştırıldığında fark bulunamamıştır (kızlar $\bar{X}=15.35$; erkekler $\bar{X}=15.45$ ).
} 
algılayan öğrencilerin ahlaki yargı yeteneği puanları ortalaması ( $\bar{X}=14.56)$ arasındaki farkın anlamlı olup olmadığ $t$ testi ile incelenmiş ve anlamlı bir fark bulunamamıştır $[t=1.102, \mathrm{p}>0.05]$.

Baba tutumlarını demokratik olarak algılayan öğrenci sayıs1 $249(\%$ $60)$, otoriter olarak alg1layan öğrenci sayıs1 ise 170 (\% 40) olarak bulunmuştur. Baba tutumlarını demokratik olarak algılayan öğrencilerin ahlaki yarg1 yeteneği puanları ortalaması ile $(\bar{X}=15.53)$ otoriter algılayan ögrencilerin ahlaki yargı yeteneği puanları ortalaması $(\bar{X}=15.16)$ arasında anlamlı bir fark bulunamamıştır [ $t=0,302, \mathrm{p}>0.05]$.

\section{TARTIŞMA VE SONUÇ}

Demokratik ve otoriter olarak algılanan ana-baba tutumlarının ahlaki yarg1 yeteneğine etkisinin incelendiği bu araştırmada, öğrencilerin ahlaki yarg1 yeteneği puan ortalamalarının lise türüne, anne ve babanın eğitim düzeyine ve ailenin algilanan sosyo-ekonomik durumuna göre farklılaşıp farklılaşmadığ incelenmiştir. Fen lisesi ve anadolu lisesi ahlaki yarg1 yeteneği puan ortalamalarının, meslek lisesi öğrencilerinin ahlaki yargı yeteneği puan ortalamalarından anlamlı düzeyde yüksek bulunmuştur.

Lise türlerine göre ahlaki yarg1 yeteneğinin farklılılaşıp farklılaşmadığı ile ilgili yurtdışı literatürde araştırmalara rastlanamamış, Türkiye'deki literatürün de sınırlı olduğu gözlenmiştir. Kaya'nın (1993) araştırma sonucu imam hatip lisesinden mezun olan öğrencilerle diğer liselerden mezun olan öğrencilerin ahlaki yargı yeteneği puanları arasında, öngörülenin aksine, anlamlı bir farklılık olmadığı yönündedir. Literatürdeki diğer araştırma sonuçları incelendiğinde, lise türleri arasında yapılan karşılaştırmalarda lise türleri ile ahlaki yargı yeteneği puanları arasında anlamlı bir ilişki olmadığı yönünde olup, araştırma sonucundan farklıdır (Çileli, 1981; Çiftçi, 2001a; Çırak, 2006).

Genel lise, fen lisesi veya anadolu lisesi gibi öncelikli hedefi üniversiteye hazırlamak olan liselerde öğrenciler seçtikleri alanlar doğrultusunda yetiştirilmektedirler. ${ }^{*}$ Meslek liseleri ile karşılaştırıldığında, bu liselerin ders programları temel ve doğa bilimleri ya da sosyal bilimler ile ilgili derslerin ağırlığının daha fazla olduğu görülmektedir. Araştırmanın; üniversiteye hazırlayan liselerde eğitim gören öğrencilerin ahlaki ikilemlere verdikleri cevaplardan aldıkları ahlaki yargı yeteneği puan ortalamalarının, meslek lisesinde öğrenim gören öğrencilerin ahlaki yarg1 yeteneği

\footnotetext{
Araştırma verilerinin toplanması sürecinde alan seçimi uygulaması yürürlükteyken, 2010- 2011 eğitim öğretim yılından itibaren alan seçimi uygulaması yerine ders seçimi uygulamasına geçilmiştir (MEB, 2004).
} 
puanlarından yüksek olduğu yönündeki bulgusunun bu durumun bir sonucu olarak açıklanabilir.

Bireyin ahlaki gelişiminde ailenin rolü önemlidir. $\mathrm{Bu}$ noktada ebeveynlerin eğitim düzeyi de önem taşımaktadır. Bu araştırmada da; ahlaki yargının annenin eğitim düzeyine göre değiştiği, annesi üniversite mezunu olan öğrencilerin ahlaki yarg1 yeteneği, annesi ilkokul mezunu olan öğrencilerinkine göre anlamlı düzeyde yüksek olduğu; bununla birlikte babanın eğitim düzeyine göre de faklılaştığı saptanmıştır: Babası üniversite mezunu olan öğrencilerin ahlaki yarg1 yeteneği puan ortalamalarının, babası ilkokul mezunu olan öğrencilerinkinden yüksek olduğu saptanmıştır. Literatürdeki benzer araştırmaların sonuçlarının da araştırmanın bulgularını desteklediği görülmüştür (Kaya, 1993; Sengün, 2003; Tola 2003; Küçükalp, 2004; Acuner, 2004; Çapan, 2005). Bunun yanında Saylağ'ın (2001) araştırmasının sonucu ahlaki değerlerin oluşmasında babanın eğitim durumunun etkili olduğu yönündedir. Literatürden farklı olarak; Çiftçi (2008) tarafından yapılan araştırma sonucu da babanın eğitim düzeyi ile ahlaki yargı yeteneği arasında ilişki olmadığ yönündedir.

Araştırmanın, anneleri üniversite mezunu olan öğrencilerin ahlaki yargı yeteneğinin anneleri ilkokul mezunu olan öğrencilerin ahlaki yarg1 yeteneği puanlarına göre anlamlı düzeyde yüksek olduğu yönündeki sonucu literatürde ulaşılan araştırmalar tarafından desteklenmektedir (Mangır ve Haktanır, 1990; İkizoğlu, 1993; Çırak, 2006). Fodor'un (1969) araştırmasında da benzer bir bulguya rastlanmış ve anneleri lise mezunu olan çocukların ahlaki yargılarının diğerlerine göre anlamlı düzeyde farklı olduğu yönündeki araştırma bulgusunun araştırmamızın sonucunu desteklediği görülmüştür.

Diğer araştırmacıların bulguları ise (Özkaynak, 1982; Koca, 1987; Kaya, 1993; Şengün, 2003, Tola, 2003; Küçükalp, 2004, Acuner, 2004; Çapan, 2005; Çiftçi, 2008 ) annenin ve babanın eğitim durumunun ahlaki yargıyı etkilemediği yönünde olup, mevcut araştırmanı bulgularından farklıdır.

Araştırmanın ahlaki yargı yeteneği ile sosyo-ekonomik düzey arasında anlamlı bir ilişki olmadığı yönündeki bulgusu hem yabancı literatürde ulaşılan bazı araştırmalar tarafından (Magsud, 1980; Lind, 1983; Hayes ve Hambright, 1984), hem de Türkiye'deki literatür tarafindan (Kaya, 1993; Şengün, 2003; Küçükalp, 2004; Çiftçi, 2008) desteklenmektedir. Bununla birlikte araştırma bulgusunu desteklemeyen araştırmalara da rastlanmıştır (Turiel, Edward ve Kohlberg, 1978; Saylağ, 2001). Ayrıca Ünsal Seydooğulları'nın (2008) araştırmasının sonucu da buradaki sonuçtan farklıdır. Yazar, "Demokratik ve Otoriter Ana Baba Tutumlarının Lisede Öğrenim Gören Öğrencilerin Ahlaki Yargı Yeteneği'ne Etkisi” başlıklı 
yüksek lisans tezinde babanın eğitim düzeyine göre öğrencilerin ahlaki yargı yeteneği puanları arasında anlamlı bir fark saptanamamıştır.

$\mathrm{Bu}$ araştırmanın bulguları, anne-baba tutumlarını demokratik ve otoriter olarak algılayan öğrencilerin ahlaki yargı yetenekleri arasında anlamlı bir fark olmadığını göstermektedir.

$\mathrm{Bu}$ konuyla ilgili yapılan araştırmalar incelendiğinde; araştırma sonuçlarının genelde bu araştırmanın sonuçlarından farklı yönde olduğu ve araştırma bulgularının daha önce yapılan araştırmalarla desteklenmediği görülmektedir.

Birçok araştırmanın bulguları, ailedeki sevgi ve güven ortamının ahlaki yarg1 yeteneğini olumlu etkilediği yönündedir (Holstein, 1972; Powers, 1988; Speicher, 1992, 1994; Loeber, 1998; Loeber \& Stouthamer-Loeber, 1996; Grusec ve diğeleri ; 2000; Taris, 2000; White \& Matawie, 2004; Glasgow ve diğerleri,, 1997; Powers, 1988; Beck, 1989; Lamb, 1993; Schickedanz, 1994, Berkowitz \& Grych, 1998; Hart, Atkins, \& Ford, 1999; Okin \& Reich, 1999; Pratt ve diğerleri, 1999; Rudy ve diğerleri, 1999; Smetana, 1999; Spinrad ve diğerleri, 1999; Walker, 1999; Walker \& Hennig, 1999; Royal \& Baker, 2005).

Bu konudaki az sayıda yapılmış olsa da Türkiye'deki araştırmalarda da (Özeri, 2001; Tola, 2003) yabancı literatürü desteklemekte olup, araştırma bulgularını desteklememektedir. Çiftçi'nin (2008) çalışması da literatürü desteklememekte fakat mevcut araştırmanın sonuçlarıyla örtüşmektedir. $\mathrm{Bu}$ araştırmadaki ahlaki yargı yeteneğinin anne baba tutumlarına göre farklılık olmadığ 1 yönündeki bulgunun nedenleri arasında ölçeklerin yapısını sayabiliriz. Araştırmada kullanılan ölçek ile anne-baba tutumları dolaylı olarak, algılanan anne-baba tutumları ölçülmektedir. Ailenin gerçekte demokratik olup olmadığını söylemek zordur. $\mathrm{Bu}$ nedenle, ailelerini demokratik ve otoriter olarak algılayan, iki grup arasında fark çıkmamış olabilir.

\section{ÖNERILER}

Lind'in rasyonel, deneysel test teorisine göre geliştirmiş olduğu Ahlaki Yargı Testi'nden sıfır ile 100 arasında puan alınabilmektedir. Test ile ölçülen ahlaki yarg1 yeteneği puan ortalaması genel olarak ülkemizde ve bu araştırmada oldukça düşüktür. Ahlaki odaklanma ve muhakeme biçiminin 30 puan ile başlayabileceği dikkate alındığında (Lind, 2008); 0-62 arasında değişen yargı puanlarının \% 87'si 30 puanın altındadır ve ortalaması da (15.38) oldukça düşüktür. Bu durumu etkileyen faktörler araştırılmalı ve irdelenmelidir.

$\mathrm{Bu}$ araştırmanın ve Türkiye'de yapılan çok sayıda araştırmanın katılımcılarının Ahlaki Yarg1 Testi ile ölçülen ahlaki yarg1 yeteneği puan ortalamasının oldukça düşük olması gençlerin ahlaki yarg1 yeteneğini 
yükseltmeye yönelik çalışmalara ağırlık verilmesi gerektiğini düşündürtmektedir. Ahlaki Yargı Testi'nin öğretmen, anne-baba ve öğrencilere uygulanarak karşılaştırmalı incelenmesi; okullarda çalışan, öğretmen, yönetici, danışman ve ebeveynlere yaşantısal eğitimler, uygulamalı KMDD sertifika eğitimi verilmesi; ayrıca rehber öğretmenlerin ailelere anne-baba tutumları, ergenlik dönemi, ergenlik dönemi gelişim özellikleri, etkili iletişim konularında seminerler ve toplantılar düzenleyerek aileleri bilinçlendirici çalışmalar yapmaları önerilebilir.

\section{KAYNAKLAR}

Acuner, H. Y. (2004). "14-18 Yaş Arası Gençlerde Ahlaki Yargı Gelişimi ve Ahlak Eğitimi." Yayımlanmamış doktora tezi. Ondokuz Mayıs Üniversitesi Sosyal Bilimler Ensitüsü, Samsun.

Baumrind, D. (1991). The influence of parenting style on adolescent competence and substance use. Journal of Early Adolescence, 11, 56-95. Beck, C. (1989). Is there really development? An alternative interpretation. Journal of Moral Education, 18 (3), 174-195.

Berkowitz, M. W.\& Grych, J. H. (1998). Fostering goodness: Teaching parents to facilitate children's moral development. Journal of Moral Education, 27 (3), 371-391.

Bilal, G. (1984). "Demokratik ve Otoriter Olarak Algılanan Ana-Baba Tutumlarının Çocukların Uyum Düzeyine Etkisi." Yayımlanmamıs doktora tezi. Hacettepe Üniversitesi Sosyal Bilimler Enstitüsü, Ankara.

Büyüköztürk, Ş., Çokluk, Ö. ve Köklü, N. (2011). Sosyal Bilimler için İstatistik (9. Baskı). Ankara: PegemAkademi.

Colby, A. \& Kohlberg, L. (1986). Das moralische urteil: Der kognitionszentrierte moralische autonomie. H. Bertram (Ed.), Gesellschaftlichen Zwang und Moralische Autonomie. (130- 162). Frankfurt .

Çapan, A. S. (2005). "3-11 Yas Çocuklarının Ahlak Gelişimlerinin Piaget'nin Ahlaki Gelişim Kuramı'na göre İncelenmesi." Yayımlanmamış yüksek lisans tezi, Marmara Üniversitesi Eğitim Bilimleri Enstitüsü, İstanbul.

Çırak K. , G. ( 2006). "Üniversite Öğrencilerinin Ahlaki Yargı Yetenekleri ve Ahlaki Yarg1 Yeteneği ile Kendini Gerçekleștirme Düzeylerinin Karşılaştırılması." Yayımlanmamış yüksek lisans tezi, Çukurova Üniversitesi Sosyal Bilimler Enstitüsü, Adana.

Çiftçi, M. (2008). "Disiplin Cezası Alan ve Almayan Lise Öğrencilerinin Ahlaki Yarg1 Yetenekleri, Bilişsel Çarpıtmaları ve Empatik Becerilerinin Karşılaştırılması". Yayımlanmamış doktora tezi, Atatürk Üniversitesi Sosyal Bilimler Enstitüsü, Erzurum.

Çiftçi, N. (2001a). "Almanya ve Türkiye'deki Lise Öğrencilerinin Ahlakî Yargı Yeteneklerinin Karşılaştırılması." Yayımlanmamış doktora tezi, Marmara Üniversitesi Sosyal Bilimler Enstitüsü, İstanbul.

Çiftçi, N. (2001b). Ahlaki Yargı Testi MUT'un Teorisi ve Türkçe Versiyonunun Geçerliği. Kuram ve Uygulamada Eğitim Bilimleri Dergisi, 1 (2), 295-321. 
Çiftçi, N. (2003a). Ahlaki Yargı Yeteneği ve Ahlak Eğitimi. H. Hökelekli (Ed.) Gençlik Dönemi ve Eğitimi (ss. 346-392). Istanbul: Ensar Neşriyat.

Çiftçi, N. (2003b). Kohlberg'in Bilişsel Ahlak Gelişimi Teorisi: Ahlak ve Demokrasi Eğitimi. Değerler Eğitimi Dergisi, 1, 43-77.

Çiftçi, N. (2012). Ahlak Gelişimi. A. Kaya (Ed.) Eğitim Psikolojsi (ss. 149-195). Ankara: Pegem Akademi Yay.

Çileli, M. (1981). "14-18 Yasları Arasındaki Öğrencilerde Ahlakî Yargının Zihinsel Gelişim Psikolojisi Yaklaşımı ile Değerlendirilmesi." Yayımlanmamış doktora tezi, Ankara Üniversitesi Eğitim Bilimleri Enstitüsü, Ankara.

Darling, N.\& Steinberg, L. (1993), Parenting style as context: an integrative model, Child development, 113, 487-496.

Dunton, K. J. (1988). Parental practices associated with their childen's moral reasoning development. A dissertation submitted To The School Of Education and The Committee on Graduate Studies Of Stanford University In Partial Fulfillment of The Requirements for The Degree of Doctor of Philosophy, Stanford University.

Durkheim, E. (1973). Erziehung, moral und gesellschaft. Neuwied und Darmstadt: Luchterhand

Fodor, E. M. (1969). Moral judgment in negro and white adolescents. Journal of Social Psychology, 79, 289-291.

Gibbs, J. C. (1991). Toward an integration of Kohlberg' s and Hoffman's theories of morality, In W. M. Kurtines ve J. L. Gewirtz (Eds.), Handbook of moral behaviour and development, 183-222, Hillsdale, NJ: Erlbaum.

Gielen, U. (1996). Kohlbergs theorie der moralischen entwicklung. In L. Kuhmerker, U.

Glasgow, K. L., Dornbush, S. M.; Troyer, L., Steinberg, L., \& Ritter, P. L. (1997). Parenting styles, adolescents' attributions aducational outcomes in nine heterogeneushigh schools. Child Development, 68, 507-529

Grolnick, W. S. \& Ryan, R. M. 1989. Parent styles associated with children's selfregulation and competence in school. Journal of educational psychology, $81,143-154$.

Grusec, J. E., Goodnow, J. J., \& Kuczynski, L. (2000). New directions in analyses of parenting contributions to children's acquisition of values. Child Development, $71,205-211$.

Hart, D., Atkins, R. \& Ford, D. (1999). Family influences on the formation of moral identity in adolescence: longitudinal analyses. Journal of Moral Education, 28 (3), 375-386.

Hayes, E. D., Hambright, J. E. (1984). Moral judgment among black adolescents white adolescents from different socioeconomic levels. The Journal of Negro Education, 53 (4).

Holstein, C. (1972). The relation of children's moral judgment level to that of their parents and to communication patterns in the family. In R. Smart and M. Smart (Eds.) Readins in child development and relationships. New York: MacMillan.

İkizoğlu, M. (1993). “"Demokratik” ve "Otoriter" Ana Baba Tutumlarının Lise Son Sınıf Öğrencilerinin Benlik Saygısı Üzerine Etkisi.” Yayımlanmamış yüksek lisans tezi Hacettepe Üniversitesi Sosyal Bilimler Enstitüsü, Ankara. 
Kaya, M. (1993). "Bazı Kişisel Değişkenlere Gore Üniversite Öğrencilerinin Ahlaki Yargıları." Yayımlanmamış doktora tezi, Ondokuz Mayıs Üniversitesi Sosyal Bilimler Enstitüsü, Samsun.

Koca, G. ( 1987). "İlkokul Birinci Sınıfa Devam Eden Yedi Yaşındaki Çocukların Ahlaki Yargılarını Etkileyen Bazı Faktörler.” Yayımlanmamış yüksek lisans tezi, Ankara Üniversitesi Fen Bilimleri Enstitüsü, Ankara.

Kohlberg, L. (1974). Zur kognitiven Entwicklung des Kindes. Frankfurt a. M: Suhrkamp. [Original: Stage and sequence: Th e cognitive-developmental approach to socialization. (1969). In D. A. Goslin (Eds.), Handbook of socialization theory and research, (pp. 347-480). Chicago, IL: by Rand MacNally \& Company.]

Kohlberg, L. \& Candee, D. (1996). Die beziehung zwischen moralischem Urteil und moralischem Handeln. In W. Althof (Ed.), Lawrence Kohlberg: Die psychologie der moralentwicklung (pp. 373-494). Frankfurt a. M.: Suhrkamp. (Original work published in 1984)

Kohlberg, L., Levine, C., \& Hewer, A. (1996). Zum gegenwaertigen stand der theorie der Moralstufen. In W. Althof (Eds.), Lawrence Kohlberg: Die psychologie der moralentwicklung (pp. 217- 372). Frankfurt a. M.: Suhrkamp. (Original work published in 1984)

Kuhmerker, L., Gielen, U., \& Hayes, R. L. (1996). Kohlbergs theorie der moralischen entwicklung. In L. Kuhmerker, U. Gielen \& R. L. Hayes (Eds.), Lawrence Kohlberg: Seine bedeutung für die paedagogische und psychologische praxis (pp. 31-58). München: Kindt Verlag.

Küçükalp, E. (2004). "Ahlaki Yargı Gelişimi ve Dindarlık Arasındaki İlişki" Yayımlanmamış yüksek lisans tezi, Uludağ Üniversitesi Sosyal Bilimler Enstitüsü, Bursa.

Lamb, S. (1993). First moral sense: an examination of the appearance of morally related behaviors in the second year of life. Journal of Moral Education, 22 (2), 97-109.

Lind, G. (1978). Wie mißt man moralisches Urteil? In G. Portele (Eds.), Sozialisation und moral (pp. 171-201). Weinheim: Beltz.

Lind, G. (1983) Moralische Urteilskompetenz und berufliche Ausbildung. Freiburg: Padagogisches Institut der Universitat Freiburg.

Lind, G. (1986). Parallelitaet von affekt und kognition in der moralischen entwicklung. In: F. Oser; W. Althof \& D. Garz (Eds.), Moralische zugaenge zum menschen - zugaenge zum moralischen menschen (pp.158-179). München: Kindt.

Lind, G. (2008). The meaning and measurement of moral judgment competence revisited A dual-aspect model. In: D. Fasko \& W. Willis (Eds.), Contemporary philosophical and psychological perspectives on moral development and education (pp.185-220).Cresskill. NJ: Hampton Press.

Lind, G. (2008a). The meaning and measurement of moral judgment competence revisited -a dual- aspect model. In D. Fasko \& W. Willis (Eds.), Contemporary philosophical and psychological perspectives on moral development and education (pp. 185-220). Cresskill, NJ: Hampton Press.

Lind, G. (2008b). Teaching students to speak up and to listen to others: Fosterin moral_democratic compentencies. In D. E. Lund \& P. R. Carr (Eds.), Doing 
democracy and social justice in education: Political literacy for all students. New York: Peter Lang Publishing.

Loeber, R., \& Stouthamer- Loeber, M. (1996). The development of offending. Criminal Justice and Behavior, 23, 12-24.Loeber, R. (1998). Developmental trajectories and risk patterns for serious juvenile delinquents and their relevance for interventions. W. Koops ve W. Slot (Eds.), Van lastig tot misdadig. Houten/Diegem, The Netherlands: Bohn Stafleu Van Loghum.

Maccoby, E. \& Martin, J., 1983. Socialization in the context of the family: parentchild interaction, P. Mussen (Eds.), Handbook Of Child Psychology, New York: Wiley. Magsud, M. (1980). Relationship between personal control, moral reasoning and socioeconomic status of Nigerian Hausa adolescents. Journal of Youth and Adolescence, 9 (4), 281-288.

Mangır, M.., Haktanır, G. (1990). A.Ü. Ziraat Fakültesi' nde Çalışan Annelerin Çocuk Yetiştirme Tutumları Üzerinde Bir Araştırma, Bilimsel Araştırmalar ve Incelemeler. A.Ü. Ziraat Fakültesi Yayınları, Ankara.

Mead, G. H. (1962/1934). Mind, self and society. Chicago: University of Chicago Press.

MEB, (Eylül, 2010). Ortaöğretim Kurumları Sinf Geçne ve Sinav Yönetmeliği.

Okin, S. M. \& Reich, R. (1999). Families and schools as compensating agents in moral development for a multicultural society. Journal of Moral Education, 28 (3), 283-298.

Özeri, Z. N. (1994). "Okul Öncesi Dönemde Ahlak Gelişimi ve Eğitimi" Yayımlanmamış yüksek lisans tezi, Marmara Üniversitesi Sosyal Bilimler Enstitüsü, İstanbul.

Özeri, Z. N. ( 2001). "Okul Öncesi Eğitim Kurumlarında Din ve Ahlak Eğitimi." Yayımlanmamış doktora tezi, Marmara Üniversitesi Sosyal Bilimler Enstitüsü, İstanbul.

Özkaynak, B. (1982). "Teğmen Kalmaz İlköğretim Okuluna Devam Eden 6-11 Yaş Grubu Çocukların Ahlaki Yargılarının Gelişimi”. Yayımlanmamış doktora tezi, Hacettepe Üniversitesi Sosyal Bilimler Enstitüsü, Ankara.

Piaget, J. (1965). The moral judgment of the child. New York: The Free Press.

Powers, S. L. (1988). Moral judgement development within the family. Journal of Moral Education, 17, 209-219.

Pratt, M. W., Arnold, M. L., Pratt, A. T. \& Diessner, R. (1999). Predicting adolescent moral reasoning from family climate: a longitudinal study. Journal of Early Adolescence, 19, 148-175.

Rousseeau, J. J. (2004/1762). Toplum Sözleşmesi (Çev: T. Yalım). Ankara: Devin Yayınları.

Royal, C. W., Baker, S. B. (2005). Effects of a deliberate moral education program on parents of elementary school students. Journal of Moral Education 34, (2), 215-230.

Rudy, D., Grusec, J. \& Wolfe, J. (1999). Implications of cross-cultural findings for a theory of family socialization. Journal of Moral Education, 28 (3), 299-310.

Saylağ, Ş. (2001). "Liselerin Birinci Sınıfında Öğrenim Gören Çocukların Ahlaki Değerleri Algılama Düzeylerinin İncelenmesi.” Yayımlanmamış yüksek lisans tez,. Hacettepe Üniversitesi Sağllk Bilimleri Enstitüsü, Ankara. 
Schickendanz, J. A. (1994). Helping children develop self-control. Childhood Education, 70, 274-278.

Seydooğulları, Ü. S. (2008). “ Demokratik ve Otoriter Ana Baba Tutumlarının Lisede Öğrenim Gören Öğrencilerin Ahlaki Yargı Yeteneği' ne Etkisi”. Yayınlanmamış yüksek lisans tezi, Sakarya Üniversitesi Sosyal Bilimler Enstitüsü, Sakarya.

Smetana, J. G. (1999). The role of parents in moral development: a social domain analysis. Journal of Moral Education, 28, 311-321.

Speicher, B. (1992). Adolescent moral judgement and perceptions of family interaction. Journal of Family Psychology, 6, 128-138

Speicher, B. (1994). Family patterns and moral judgement during adolescence and early childhood. Developmental Psychology, 30, 624-632

Spinrad, T., Losoya, S., Eisenberg, N., Fabes, R., Shepard, S., Cumberland, A., Guthrie, I. \& Murphy, B. (1999). The relations of parental affect and encouragement to children's moral emotions and behaviour. Journal of Moral Education, 28 (3), 323-337.

Steinberg, L., Lamborn, S., Darling, N., Mounts, N. \& Dornbusch, S., (1994). Overtime changes in adjustment and competence among adolescents from authoritative, authoritarian, indulgent, and neglectful families. Child Development, 65, 754- 770 .

Şengün, M. (2003). "Ahlaki Düşünce ve Yargıları Etkileyen Bazı Faktörlerin İncelenmesi." Yayımlanmamış yüksek lisans tezi, Ondokuz Mayıs Üniversitesi Sosyal Bilimler Enstitüsü, Samsun.

Şengün, M. (2008). ’'Lise Öğrencilerinin Ahlaki Olgunluk Düzeylerinin Bazı Kişisel Değişkenler Açısından İncelenmesi. “ Yayımlanmamış doktora tezi, Ondokuz Mayıs Üniversitesi Sosyal Bilimler Enstitüsü, Samsun.

Taris, T. W. (2000). Quality of mother- child interaction and the intergenerational transmission of sexual values: A panel study. The Journal of Genetic Psychology, 161 (2), 169-181.

Tola, D. (2003). "İlkokul 5. Sınıf Çocuklarında Ahlaki Yargı ile Ana Baba Tutumları Arasındaki İlişkinin İncelenmesi.” Yayımlanmamış yüksek lisans tezi, Gazi Üniversitesi Eğitim Bilimleri Enstitüsü, Ankara.

Turiel, E., Edwards, C. P. \& Kohlberg, L. (1978). Moral development in Turkish children, adolescents and young adults. Journal of Cross-Cultural Psychology, 9 (1), 75-86.

Walker, L. J. (1999). The perceived personality of moral exemplars. Journal of Moral Education, 28 (2), 145-162.

Walker, L. J. \& Hennig, K. H. (1999). Parenting style and the development of moral reasoning. Journal of Moral Education, 28 (3), 359-374.

White, F. A. (2000). Relationship of family socialization processes to adolescent moral thought. The Journal of Social Psychology, 140 (1), 75-91.

White, F. A. \& Matawie, K. M. (2004). Parental moral and family processes as predictors of adolescent morality. Journal of Child and Family Studies, 13 (2), 219-233. 